\title{
Effect of Fe-Zn-Mg-Al hydrotalcites on the methane potential of synthetic wastewater
}

\begin{abstract}
Three hydrotalcites of $\mathrm{M}^{2+}-\mathrm{Mg}-\mathrm{Al}$ were synthesized using the co-precipitation method, where $\mathrm{M}^{2+}$ was $\mathrm{Fe}^{2+}, \mathrm{Zn}^{2+}$ and $\mathrm{Fe}^{2+}+\mathrm{Zn}^{2+}$. The hydrotalcites and their calcined form of mixed oxides obtained by their thermal decomposition were characterized by FTIR, XRD and SEM. Subsequently their effect on the methane potential of synthetic wastewater comprised of sucrose and sulfur was evaluated in a multiple batch system at $37 \pm 0.5$ ${ }^{\circ} \mathrm{C}$. The best methane potential was observed from the Fe-Zn-Mg-Al hydrotalcite at $500 \mathrm{mg} / \mathrm{L}$ yielding $3712 \mathrm{~mL}$ $\mathrm{CH}_{4} / \mathrm{gVS}$ which corresponds to an $8.1 \%$ increment against the control. The better performance of the Fe- $\mathrm{Zn}$ $\mathrm{Mg}-\mathrm{Al}$ hydrotalcite can be attributed to the $\mathrm{Zn}^{2+}$ ions. These react with $\mathrm{S}^{2-}$ in the substrate to yield zinc sulfide and therefore prevent it from forming $\mathrm{H}_{2} \mathrm{~S}$ by sulfate reducing bacteria, meanwhile reducing competition for methanogens to form methane. Calcined hydrotalcites neither stimulated nor inhibited the methane production which suggests that the enhancement of methane produced by the Fe-Zn-Mg-Al hydrotalcite was related to the presence of $\mathrm{Fe}^{2+}$ and $\mathrm{Zn}^{2+}$ cations incorporated and immobilized in the layered sheet structure of the hydrotalcite.
\end{abstract}

\section{Introduction}

The ongoing need to promote the production and use of renewable energy has opened way to research for improving the mature technologies found nowadays. Upgrading and optimization of industrial process design has led to increased energy efficiencies where a main focus is also energy recovery. Anaerobic digestion of organic waste and wastewater is a well-established treatment technology, it not only destroys pathogenic organisms and reduces problems associated with management and disposal of waste, but it also allows potential energy recovery in the form of methane-rich biogas. Methane derived via anaerobic digestion is often described as an ideal fuel (Chynoweth et al. 2001; Mes et al. 2003; Meyer \& Edwards 2014). It requires low energy to be produced; it generates less carbon dioxide per unit energy and few atmospheric pollutants. Methane can be easily distributed with existing pipelines making it available for domestic, municipal and industrial use and depending on its purity it can be used for appliances, vehicle fuel, industrial applications and power generation.

Anaerobic digestion is widely applied as wastewater treatment in various types of industries and commonly in agriculture and the municipal sector. However for the pulp and paper industry it has received attention only in the recent past years. The pulp and paper industry is one of the most water consuming industries and although much effort has and is been implemented in reducing their water footprint it still generates high volumes of wastewaters, from 13 to $30 \mathrm{~m}^{3}$ of water per ton of produced paper, with very particular characteristics (Kamali and Khodaparast 2014). One of the common characteristic is the presence of sulfur compounds due to the chemicals used in kraft pulping; which is the most widely used type of chemical pulping. Kraft pulping uses hydrogen sulfite $\left(\mathrm{HSO}_{3}{ }^{-}\right)$as the main chemical, resulting in sodium sulfide $\left(\mathrm{Na}_{2} \mathrm{~S}\right)$, sodium sulfate $\left(\mathrm{Na}_{2} \mathrm{SO}_{4}\right)$, sodium sulfite $\left(\mathrm{Na}_{2} \mathrm{SO}_{3}\right)$ and sodium thiosulfate $\left(\mathrm{Na}_{2} \mathrm{~S}_{2} \mathrm{O}_{3}\right)$ present in the process effluent (Ekstrand et al. 2013) 
Wastewaters are also characterized by high biochemical oxygen demand (BOD) , high chemical oxygen demand (COD), chlorinated compounds (measured as adsorbable organic halides AOX), suspended solids (mainly fibers), fatty acids, tannins, resin acids, lignin and other wood extractives (Ekstrand et al. 2013; Ali \& Sreekrishnan 2001).

Usually pulp and paper mills treat their wastewaters in aerobic activated sludge plants, which consequently create large production of waste sludge. This led to an increase of studies on various pretreatment methods in order to enhance the methane potential of pulp and paper sludge (Bayr et al. 2013; Elliott \& Mahmood, 2007; Yunqin et al. 2010; Meyer \& Edwards 2014). Buyukkamaci and Koken, 2010 explain the economic and effective alternative of combining anaerobic wastewater treatment with aerobic post treatment. This is due to the fact that in most cases the application of only anaerobic treatment does not deliver treated effluent of sufficient quality. However by implementing anaerobic treatment first, it reduces the organic load to the aerobic treatment; which in many cases is overloaded; and causes less sludge production. Moreover there is the potential of energy recovery which gives the economic incentive. Nonetheless, few literature is found on the anaerobic digestion and methane enhancement of pulp and paper wastewater.

Meyer and Edwards 2014 reviewed the anaerobic digestion and methane potential of different effluents coming from pulp and paper mills. Depending of the type of pulping and the chemical used during the pulping process the COD removal and methane productions vary greatly. They found that condensate streams from chemical pulping have the highest COD removal rates (75-90\%). The lowest rates correspond to chemical sulfite pulping effluents (29-38\%) and debarking effluents (44-70\%) from the mechanical pulping; mostly due to sulfur inhibition and concentration of lignin and resins respectively. Methane production followed the same pattern. Bleaching effluents in general were found to have inhibitory compounds for anaerobic digestion having the lowest methane production (0-380 $\mathrm{mL} \mathrm{kg}^{-1} \mathrm{COD}$ removed). Effluents with the highest methane potential were from the neutral sulfite chemical pulping (NSSC) condensate $\left(380-400 \mathrm{~mL} \mathrm{~kg}^{-1}\right.$ COD removed), where there is high acetic acid concentrations contributing to the direct formation of methane. They concluded that the numerous studies conducted show that, contrary to common perception, most mill effluents were to some extent anaerobically treated even the difficult to digest streams. This suggests the possible enhancement of methane production of these effluents by means of pretreatment, co-digestion or catalysis.

Hydrotalcites (HTs) or layered double hydroxides are anionic clays that have a broad spectrum of applications such as catalysts, pharmaceuticals, absorbents, ion exchangers and many more applications arising due to the possibility of designing them tailored to specific reactions and/or substrates (Carriazo et al. 2007; Wimonsong et al. 2013). HTs and their calcined products have also gained attention in wastewater treatment and purification for its high ion-exchange capacities for adsorption of various anionic pollutants which include bromide, arsenic, lead, fluorine, chromate and other toxic anions (Setshedi et al. 2011; Gillman 2006; Wajima 2014; Wang et al. 2007, Palmer \& Frost 2010; Cocheci et al. 2010). Douglas et al. 2009 studied the formation and effect of HTs in the treatment of mining wastewater and acidic wastewaters. They report results of optimal removal of a broad spectrum of contaminants from the wastewaters, including uranium. HTs have also been employed to increase hydrogen production in fermentation processes (Wimonsong et al.2013 and Wimonson et al. 2014). 
HTs compounds have a brucite-like structure with stacked layers of metal cations following the general formula of $\left[\mathrm{M}_{1-\mathrm{x}}{ }^{2+} \mathrm{M}_{\mathrm{x}}{ }^{3+}(\mathrm{OH})_{2}\right]\left[\mathrm{A}_{\mathrm{x} / \mathrm{m}}\right]^{\mathrm{m}-} \cdot \mathrm{nH}_{2} \mathrm{O}$, where $\mathrm{M}^{2+}$ is a divalent cation, $\mathrm{M}^{3+}$ is a trivalent cation, $A$ an interlamellar anion with charge $\mathrm{m}^{-}$and $\mathrm{x}$ is the ratio of $\mathrm{M}^{+3} /\left(\mathrm{M}^{+2}+\mathrm{M}^{+3}\right)$ (Palmer \& Frost 2010). In the following investigation two possible anions $\left(\mathrm{Fe}^{2+}\right.$ and $\left.\mathrm{Zn}^{2+}\right)$ in the $\mathrm{HT}$ structure were chosen for the possibility to improve the digestion process and methane potential of the substrate. Iron functionality in the anaerobic process is well known (Jackson-Moss \& Duncan 1990). Iron is essential for microbial growth and is an important component of many of the enzymes involved in the metabolic pathways of bacteria; it also enhances the granulation process. Methanogens have a specific growth requirement for iron, and concentrations of $2.6 \mathrm{~g} \mathrm{~L}^{-1}$ of $\mathrm{FeCl}_{2}$ have increased conversion of acetic acid to methane. However if present in high concentrations $\left(5.6 \mathrm{~g} \mathrm{~L}^{-1}\right)$ it becomes toxic (Hoban and Van den Berg, 1979; Jackson-Moss \& Duncan 1990). Though iron is one of the most abundant elements, its bioavailability is limited since the majority is in the insoluble 3+ state. Casals et al. 2014 studied iron oxide nanoparticles in anaerobic digesters and found an increase in biogas production of up to $40 \%$ when $0.15 \mathrm{mg} / \mathrm{mL}$ iron sulfate was added, concentrations higher than resulted in a dramatic decrease in biogas production. Zinc was chosen for its ability to remove sulfur components (Sekhavatjou et al. 2014; Wu et al. 2011). Another key characteristics is the nano-scale particle size of HTs, this provides large surface areas (20$120 \mathrm{~m}^{2} / \mathrm{g}$ ) that may possibly boost bacterial anchoring in the anaerobic process (Lv et al. 2007). Nanoparticles have the advantage of reacting rapidly with the electron donors leading to kinetic improvements and also act as biocatalysts enhancing the activity of microorganisms (Beckers et al, 2013). In this study, $\mathrm{M}^{2+}-\mathrm{Mg}$-Al HTs with combinations of metal ions, where $\mathrm{M}^{2+}$ is Fe and/or Zn were synthesized with the co-precipitation method and characterized. Moreover their effect on the methane potential of synthetic wastewater was evaluated.

\section{Materials and Methods}

\subsection{Hydrotalcite preparation}

Hydrotalcites of $\mathrm{M}^{2+}-\mathrm{Mg}$-Al were synthesized using the co-precipitation method as described in the literature (Salomão, et al. 2011), where $\mathrm{M}^{2+}$ was $\mathrm{Fe}^{2+}, \mathrm{Zn}^{2+}$ and $\mathrm{Fe}^{2+}+\mathrm{Zn}^{2+}$. The ratio between the molar fraction of divalent and trivalent cations $\left(\mathrm{M}^{2+} / \mathrm{M}^{3+}\right)$ was 3:1. In this method two solutions were prepared. The first aqueous solution consisted of a $300 \mathrm{~mL}$ mixture of metal nitrates of $\mathrm{Mg}\left(\mathrm{NO}_{3}\right)_{2} \cdot 6 \mathrm{H}_{2} \mathrm{O}$ and $\mathrm{Al}\left(\mathrm{NO}_{3}\right)_{3} \cdot 9 \mathrm{H}_{2} \mathrm{O}$ and/or $\mathrm{FeSO}_{4} \cdot 7 \mathrm{H}_{2} \mathrm{O}$, and $\mathrm{Zn}\left(\mathrm{NO}_{3}\right)_{2} \cdot 6 \mathrm{H}_{2} \mathrm{O}$ in the desired molar ratios. The second solution was prepared by dissolving $\mathrm{NaOH}(2.25 \mathrm{M})$ and $\mathrm{Na}_{2} \mathrm{CO}_{3}(0.45 \mathrm{M})$ in $300 \mathrm{~mL}$ of distilled water. The second solution was added to the first solution dropwise at a rate of $50 \mathrm{~mL} / \mathrm{h}$ under vigorous stirring until the $\mathrm{pH}$ reached around 9-10. The thick slurry formed was aged in a thermostatic bath for 18 hours at $60^{\circ} \mathrm{C}$. Afterward, the slurry was filtered and washed thoroughly with deionized water in order to remove the alkaline metals and nitrate ions until the filtrate effluent reached a neutral $\mathrm{pH}$. Finally, the filter cake was dried at $110^{\circ} \mathrm{C}$ for 24 hours and ground in a mortar. Calcined HTs were obtained by placing ground HTs in a muffle furnace at $500^{\circ} \mathrm{C}$ for 4 hours.

\subsection{Hydrotalcite characterization techniques}

The structures of HTs as prepared and after calcination were analyzed by X-ray diffraction (XRD) technique using a Bruker D8 instrument equipped with a $\mathrm{Cu}$ target and a graphite monochromator. XRD patterns were recorded at $40 \mathrm{kV}$ and $40 \mathrm{~mA}$ by using Cu radiation $(\lambda=0.15406 \mathrm{~nm})$ at a rate of $0.02^{\circ} /$ second from $2 \theta=5^{\circ}$ to 
$75^{\circ}$. The average crystals sizes (Dc) were estimated from full width at half maxima (FWHM) of the XRD peak with maximum intensity by using Scherrer Equation (1).

$$
D c=\left(K\left(\frac{\lambda}{\beta}\right) \cdot \cos \theta^{-1}\right)
$$

where $K$ is the Scherrer constant (0.89), $\lambda$ is the X-ray wavelength (1.54 $\AA$ ), $\beta$ is the line broadening at half the maximum intensity (FWHM) in radians, and $\theta$ is the diffraction angle. Fourier transform infrared spectroscopy (FTIR) was carried out with a Nicolet 6700 FTIR spectrometer. Spectra were recorded with a resolution of $4 \mathrm{~cm}^{-1}$ over the wavenumber range $4000-400 \mathrm{~cm}^{-1}$. The morphologies of the HT samples were examined with a Neon40 scanning electron microscope (SEM) Crossbeam Station (Zeiss) equipped with a field emission electron source. For size distribution histograms of 100 particle measurements were taken.

\subsection{Inocullum and substrate for BMP}

Biochemical Methane Potential (BMP) tests were performed in batch experiments to determine the HTs effect on methane production. The inoculum used for experiments originated from Suomenoja municipal wastewater treatment plant located in Espoo, Finland. It was taken fresh from their mesophilic anaerobic digester and degassed at the same operating temperature $\left(37.0^{\circ} \mathrm{C}\right)$ prior to the start of the experiment. Analyses resulted in total solids (TS\%) of $1.64 \pm 0.05$, volatile solids (VS\%) of $0.88 \pm 0.04$, and moisture content (\%) of $98.36 \pm 0.05$. Values represent the average \pm STD of three samples. A pH value of 7.3 was measured at the start of the experiments, total alkalinity (TA) of $6.3 \mathrm{~g} \mathrm{CaCO}_{3} / \mathrm{L}$ and a conductivity of $6.32 \mathrm{mS} / \mathrm{cm}$.

The substrate used for this study was synthetic wastewater simulating the composition of pulp and paper wastewater which includes average COD concentration of $5000 \mathrm{mg} \mathrm{COD} / \mathrm{L}$ and $200 \mathrm{mg} / \mathrm{L}$ average concentration of sulfate. The synthetic wastewater used in the experiments comprised of (mg/L): sucrose $\left(\mathrm{C}_{12} \mathrm{O}_{22} \mathrm{O}_{11}\right) 3000$; sodium acetate $\left(\mathrm{C}_{2} \mathrm{H}_{3} \mathrm{NaO}_{2}\right)$ 2000; magnesium sulfate $\left(\mathrm{MgSO}_{4}\right)$ 1540; ammonium chloride $\left(\mathrm{NH}_{4} \mathrm{Cl}\right) 950$; potassium dihydrogen phosphate $\left(\mathrm{KH}_{2} \mathrm{PO}_{4}\right) 220$; Calcium chloride $\left(\mathrm{CaCl}_{2}\right) 150$ and sodium bicarbonate $\left(\mathrm{NaHCO}_{3}\right)$ 2000. Substrate was prepared to achieve a ratio of COD:N:P of 100:5:1 to ensure nutrient requirements, it was later stored at $4^{\circ} \mathrm{C}$ prior to its use. The fresh substrate was analyzed using average values of triplicates resulting in total solids (TS\%) of 0.73 , volatile solids (VS\%) of 0.35 , moisture content (\%) of 99.26, COD of $5000 \mathrm{mg} / \mathrm{L}, \mathrm{pH}$ of 7.66 and conductivity of $6.98 \mathrm{mS} / \mathrm{cm}$. The elemental composition of the substrate was $\mathrm{C}(25.21 \%), \mathrm{H}(3.82 \%)$, $\mathrm{N}(0.10 \%)$, and S (2.35\%).

\subsection{Experimental design}

Experiments in order to test the effect of HTs addition were carried out in an automatic methane potential test system (AMPTS II), which is a laboratory scale, multiple batch system developed for automatic real-time logging and measuring of methane production (Rodriguez-Chiang and Dahl 2015; Badshah et al. 2012; Browne and Murphy 2013; Browne et al. 2013). Measurements are expressed using the same unit for conventional BMP test found in literature; normalized $\mathrm{mL}$ of methane per gram of volatile solids added ( $\left.\mathrm{NmL} \mathrm{CH}_{4} / \mathrm{gVS}\right)$. It has a capacity for incubating 15 reactors of $500 \mathrm{~mL}$ each with an individual mixing motor and a defined carbon dioxide removal step in order to provide methane yield. 
Three different hydrotalcites were evaluated: Fe-Mg-Al, Zn-Mg-Al and Fe-Zn-Mg-Al, as well as each one in its calcined form. Methane potential of samples were initially evaluated by adding $500 \mathrm{mg} / \mathrm{L}$ of HT, which was the optimal dose found in Wimomsong et al. 2013 for the production of hydrogen and the same optimal dose suggested by Terry et al. 2012 for the removal of $\mathrm{Cr}(\mathrm{VI})$ from aqueous solution with hydrotalcite. This concentration is equivalent to a ratio of $\mathrm{HT}: \mathrm{COD}$ of $0.1: 1$. The HT that produced the highest methane increment was later tested at different ratios in order to evaluate the effect of HT concentration. All samples were prepared in triplicates for statistical significance. The BMP tests were carried out using a working volume of $400 \mathrm{~mL}$ and an inoculum to substrate ratio of 2, in order to ensure enough microbial population as suggested in Angelidaki et al. (2009). Triplicate blank samples with no substrate were run to determine the produced background methane originating from the inoculum alone. Triplicate control samples containing only inoculum and substrate and no hydrotalcite addition were run in parallel. After filling each reactor, bottles where sealed with a hermetic rubber stopper connected to a mechanical agitator and placed in a water incubator at $37.0 \pm$ $0.5{ }^{\circ} \mathrm{C}$. To chemically remove carbon dioxide $\left(\mathrm{CO}_{2}\right)$ and hydrogen sulfide $\left(\mathrm{H}_{2} \mathrm{~S}\right)$ formed during anaerobic digestion, each reactor was individually connected to another small bottle containing $80 \mathrm{~mL}$ of an alkali solution of $3 \mathrm{M} \mathrm{NaOH}$. Thymolphthalein $\mathrm{pH}$ indicator was added to each bottle to determine when the solution has been spent and needed replacement. Each alkali solution bottle was then connected to the measuring device and finally all reactors where flushed with pure nitrogen gas $\left(\mathrm{N}_{2}\right)$ for $5 \mathrm{~min}$, to ensure anaerobic conditions.

\subsection{Analytical methods}

Total solids (TS), volatile solids (VS), and moisture content in fresh samples of substrate and inoculum were determined gravimetrically following Standard Methods described in APHA (2005). COD was measured by Standard Method 5220. Total alkalinity (TA) to $\mathrm{pH} 4.5$ was measured by Standard Method $2320 \mathrm{~B}$. The pH measurements were performed using a $\mathrm{pH}$ meter Thermo Scientific model Orion 2-star pH-Benchtop. Conductivity was taken with a conductivity meter Orion Model 150. Elemental analysis of the substrate was determined by duplicate samples using a Perkin Elmer Model 2400 Series II CHNS Elemental Analyzer (USA).

Methane production was measured using the AMPTS II from Bioprocess Control AB, Sweden (System Version 2.0 V1.08), which works by the principle of liquid displacement and buoyancy. Volumes of gas are corrected to standard temperature and pressure (STP) conditions at $273 \mathrm{~K}$ and $1013 \mathrm{mbar}$ air pressure. Biochemical methane potential was calculated as the accumulated methane produced per gram of VS added to each reactor, as determined in Eq. (2) (Strömberg et al. 2014),

$$
B M P=\frac{V_{\text {sample }}-V_{\text {inoc }} \frac{g V S i s}{g V S i b}}{g V S_{\text {substrate }}}
$$

where $B M P$ is the normalized volume produced per gram VS of substrate added $\left(\mathrm{mLCH}_{4} / \mathrm{gVS}\right), \mathrm{V}_{\text {sample }}$ is the mean value of accumulated methane produced from the reactor with both inoculum and substrate, $V_{\text {inoc }}$ is the mean value of the accumulated volume produced by the blanks with only inoculum, $g V S_{\text {is }}$ is the mass of volatile solids of the inoculum added in the sample, $g \mathrm{VS}_{i b}$ is the mass of volatile solids of the inoculum added in the blanks, and $g V S_{\text {substrate }}$ is the mass of volatile solids of the substrate added in the reactor. 


\section{Results and discussion}

\subsection{Hydrotalcite characterizations}

The X-ray diffraction profiles of the HTs prepared are shown in Fig. 1. All diffractograms showed a similar pattern, characteristic of a well crystallized HT structure described in the literature (Miranda et al. 2014, Wimomsong et al, 2013). Sharp peaks were observed at low diffraction angles of $2 \theta: 11^{\circ}, 23^{\circ}$, and $35^{\circ}$, corresponding to the crystal planes of (003), (006) and (012) respectively. Broader peaks were observed at $2 \theta$ : $39^{\circ}, 46^{\circ}, 61^{\circ}$, and $62^{\circ}$ corresponding to the crystal planes of (015), (018), (110), and (113) respectively; also representative for hydrotalcite-like compounds. The characteristic peaks for the Fe-Mg-Al HT were somewhat broader, which indicated that the HTs samples containing $\mathrm{Fe}^{2+}$ were smaller in size. This result is validated by the estimated average crystal size using the Scherrer equation. The lattice parameters were calculated for a hexagonal unit cell on the basis of rhombohedral R-3m symmetry. Crystal size and lattice parameters of HTs are shown in Table 1. The parameter " $a$ " $\left(a=2 \cdot d_{110}\right)$ was calculated as cation-cation distance within the brucitelike layer while the parameter " $c$ " $\left(c=3 \cdot d_{003}\right)$ is related to the thickness of the brucite-like layer and the interlayer distance (Ohishi et al. 2005). The decrease in the lattice parameter for the Fe HT samples is due to the radius of the divalent metal $\left(\mathrm{Fe}^{2+}=0.061 \mathrm{~nm}\right)$, which is smaller than the radius of $\mathrm{Mg}^{2+}=0.072 \mathrm{~nm}$ and $\mathrm{Zn}^{2+}$ $=0.074 \mathrm{~nm}$.

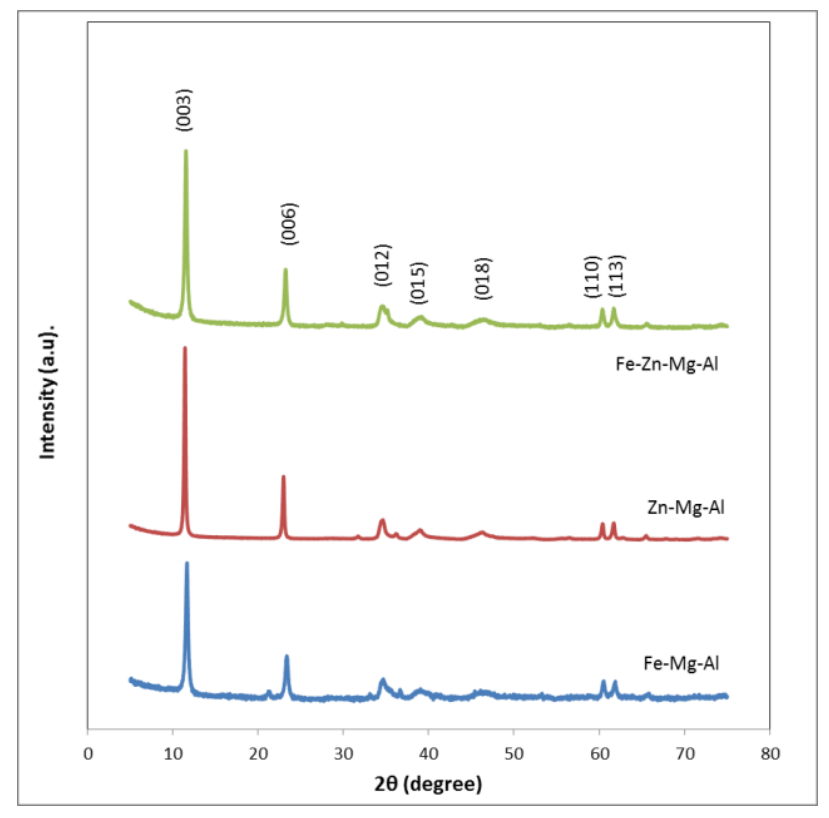

Fig. 1 X-ray diffractograms of HTs

Table 1. HTs lattice parameters and crystal sizes from XRD

\begin{tabular}{|c|c|c|c|c|c|}
\hline HT sample & $\begin{array}{c}\text { Atomic ratio } \\
\mathrm{M}^{2+}: \mathrm{Mg}^{2+}: \mathrm{Al}^{3+}\end{array}$ & Chemical formula & \multicolumn{2}{|c|}{$\begin{array}{c}\text { Lattice } \\
\text { parameters }\end{array}$} & $\begin{array}{c}\text { Crystal } \\
\text { size }\end{array}$ \\
\cline { 4 - 5 } & & & $a(\AA)$ & $c(\AA)$ & $(\mathrm{nm})$ \\
\hline
\end{tabular}




\begin{tabular}{|l|l|l|l|c|c|}
\hline Fe-Mg-Al & $0.5: 2.5: 1$ & {$\left[\mathrm{Fe}_{0.5} \mathrm{Mg}_{2.5} \mathrm{Al}(\mathrm{OH})_{8}\right]\left(\mathrm{CO}_{3}\right)_{0.5} \cdot 2.5 \mathrm{H}_{2} \mathrm{O}$} & 3.056 & 22.800 & 25 \\
\hline Zn-Mg-Al & $0.5: 2.5: 1$ & {$\left[\mathrm{Zn}_{0.5} \mathrm{Mg}_{2.5} \mathrm{Al}(\mathrm{OH})_{8}\right]\left(\mathrm{CO}_{3}\right)_{0.5} \cdot 2.5 \mathrm{H}_{2} \mathrm{O}$} & 3.062 & 23.220 & 39 \\
\hline Fe-Zn-Mg-Al & $0.25: 0.25: 2.5: 1$ & $\begin{array}{l}{\left[\mathrm{Zn}_{0.25} \mathrm{Fe}_{0.25} \mathrm{Mg}_{2.5} \mathrm{Al}\right.} \\
\left.(\mathrm{OH})_{8}\right]\left(\mathrm{CO}_{3}\right)_{0.5} \cdot 2.5 \mathrm{H}_{2} \mathrm{O}\end{array}$ & 3.064 & 22.971 & 28 \\
\hline
\end{tabular}

The XRD profiles recorded from calcined HTs can be observed in Fig. 2. Calcination of hydrotalcites induces the formation of the corresponding $\mathrm{Mg}$-Al oxides as well as removal of hydroxyl groups and interlayer anions. The presence of diffraction peaks are clearly observed at $2 \theta=43^{\circ}$ and $63^{\circ}$ which correspond to a MgO-like phase (periclase) [Wenlei Xie 2006]. Peaks of $\mathrm{Al}_{2} \mathrm{O}_{3}$ phase are almost absent, indicating that $\mathrm{Al}^{3+}$ cations are dispersed in the structure of $\mathrm{MgO}$ or forming an amorphous phase. Calcined $\mathrm{Zn}-\mathrm{Mg}$-Al HT exhibited peaks corresponding to the formation of zinc oxide. By application of the Scherrer equation the crystal sizes of calcined HTs were determined: Fe-Mg-Al, 4 nm; Zn-Mg-Al, $5 \mathrm{~nm}$ and Fe-Zn-Mg-Al, $4 \mathrm{~nm}$. This indicated the smaller size crystals compared to the uncalcined samples and which is also observed through SEM.

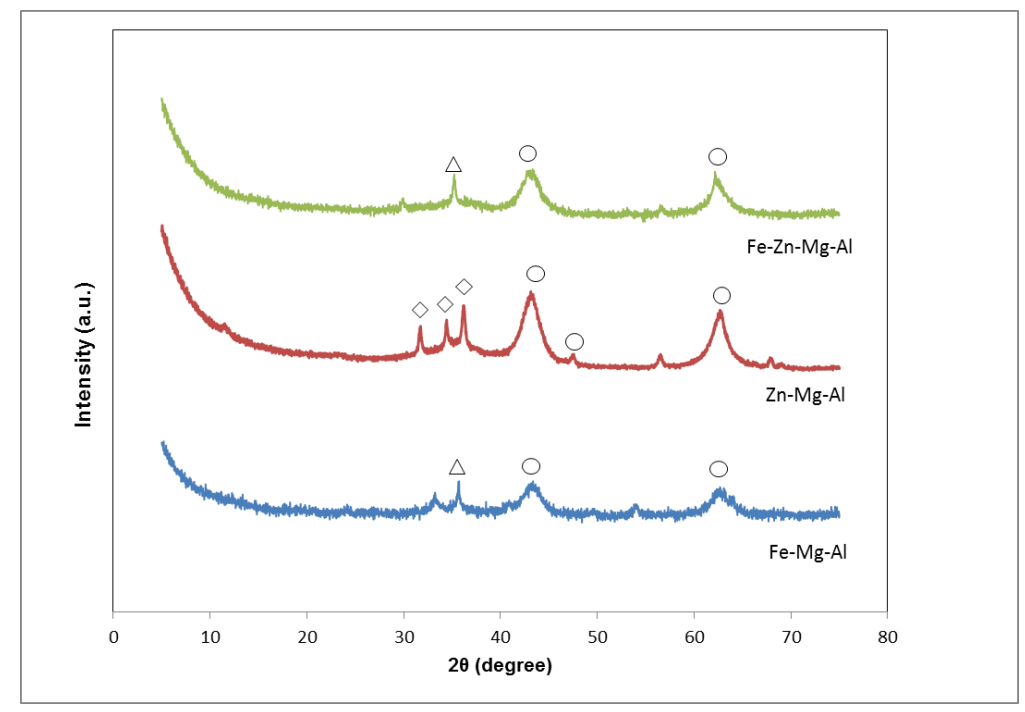

Fig. 2 X-ray diffractograms of calcined HTs. $\bigcirc \mathrm{MgO}$ (periclase), $\triangle \mathrm{Al}_{2} \mathrm{O}_{3}, \diamond \mathrm{ZnO}$

FTIR spectra of the HTs are shown in Fig.3. In all the samples, a broad absorption band in the range of $3400-$ $3500 \mathrm{~cm}^{-1}$ and $1610-1650 \mathrm{~cm}^{-1}$ are designated to the $\mathrm{O}-\mathrm{H}$ stretching vibration and bending vibration of interlayer water molecules, respectively (Cocheci et al. 2010). The strong peak at $1365 \mathrm{~cm}^{-1}$ indicates the presence of the carbonate anion in the interlayer region of the HTs. The bands in the interval of $500-800 \mathrm{~cm}^{-1}$ are attributed to a stretching of metal-oxygen bonds. 


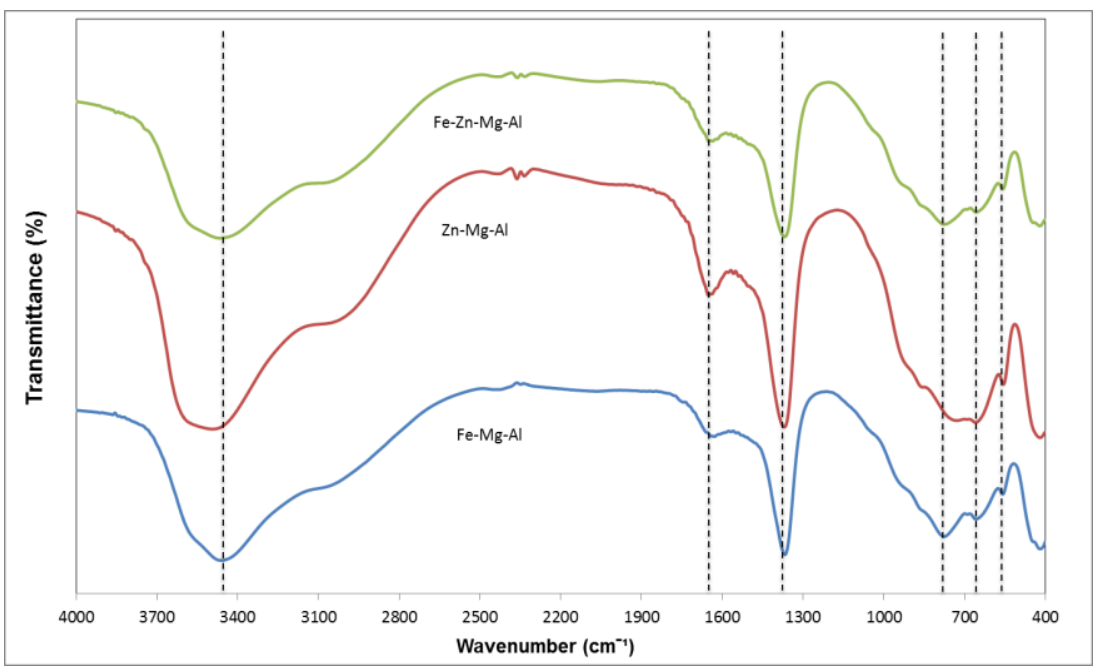

Fig. 3. FTIR spectra of HTs.

The morphology of the HTs was analyzed by SEM. Fig. 4. shows representative images; in all cases there was a very homogeneous distribution of crystal aggregates. For uncalcined HT samples the average aggregate size was 50-60 $\mathrm{nm}$ and in calcined samples aggregates ranged from $40-50 \mathrm{~nm}$.

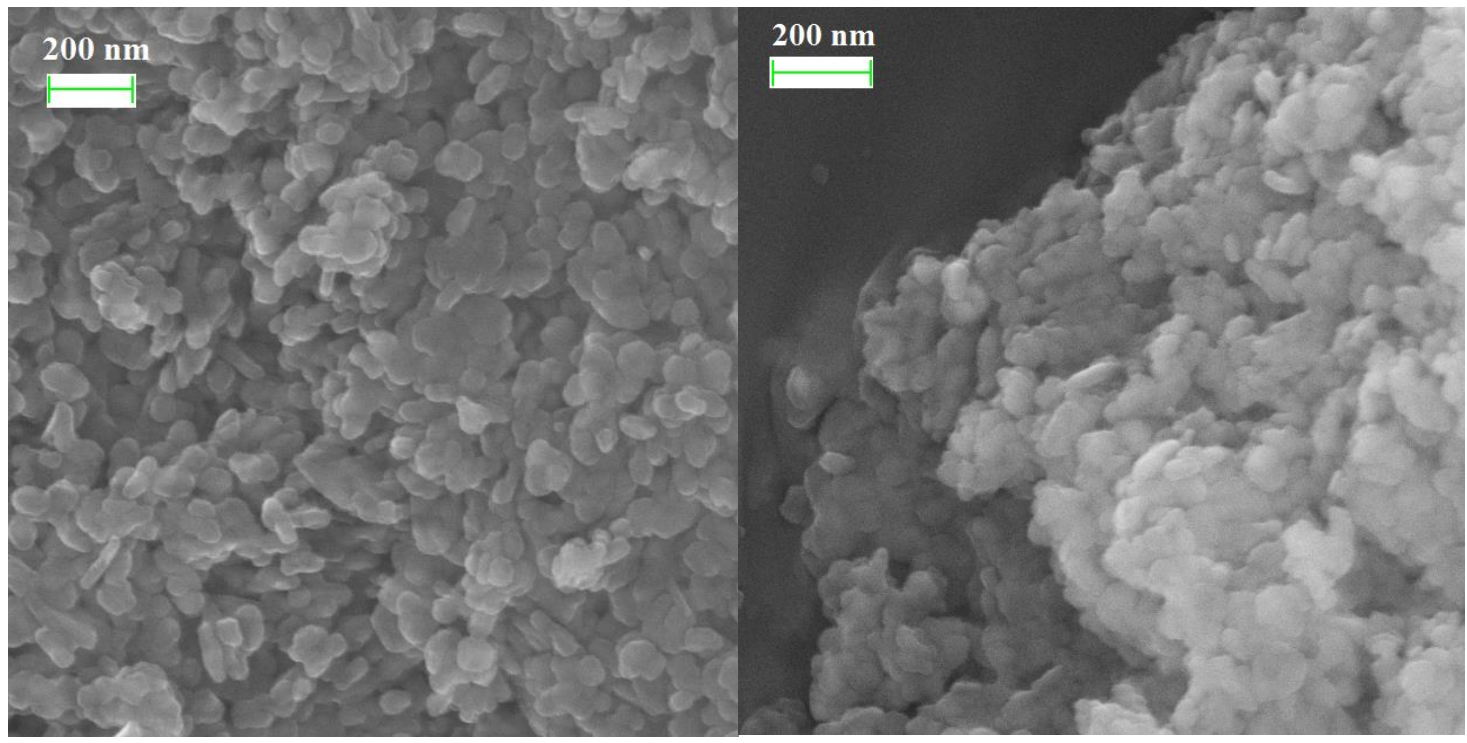

Fig. 4. SEM images for uncalcined Fe-Zn-Mg-Al HT sample (left) and calcined HT sample (right)

Energy dispersive X-ray analyses were carried out on different areas of the samples and in all cases the relative amount of $\mathrm{M}^{2+}: \mathrm{M}^{3+}$ matched the nominal 3:1 value. 


\subsection{Methane production and hydrotalcite effect}

The methane production of synthetic wastewater was tested with the produced hydrotalcites. Initially, all three HTs and their calcined form were tested at a concentration of $500 \mathrm{mg} / \mathrm{L}$. The respective accumulated methane yields of samples can be observed in Figure 5.

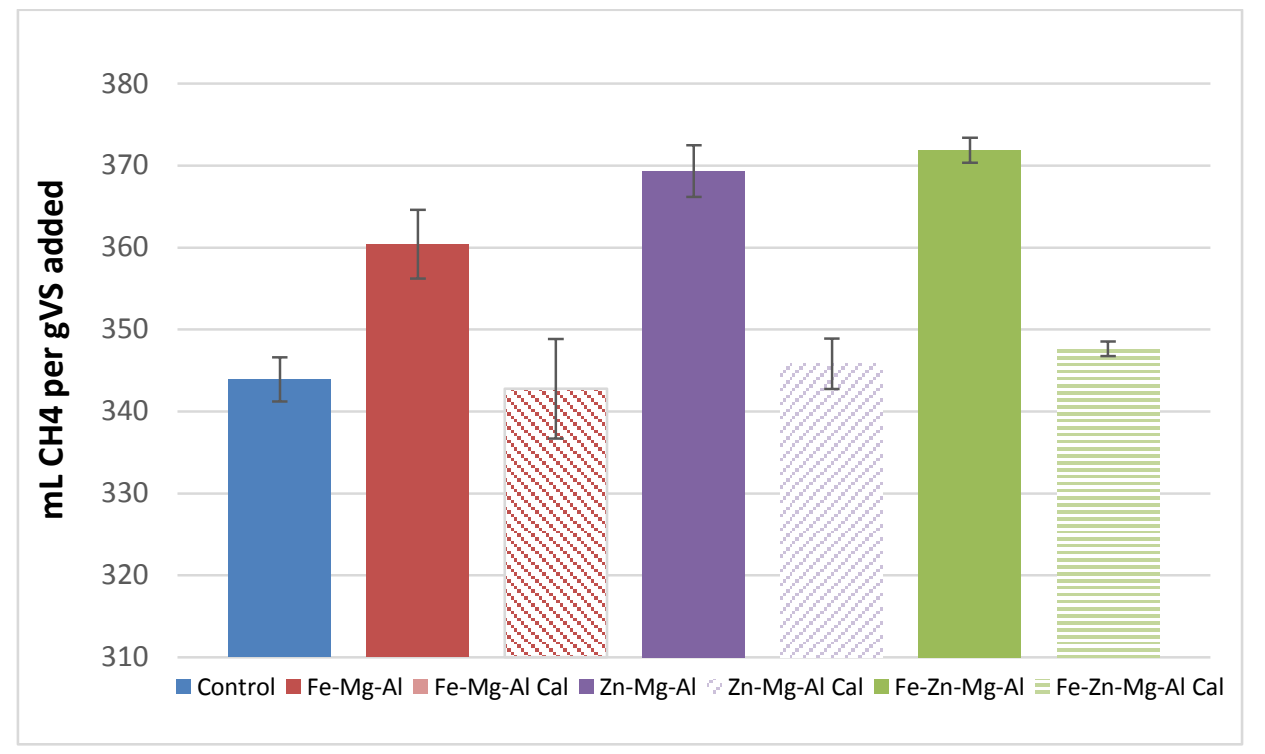

Figure 5. Accumulated methane production of each HT at $500 \mathrm{mg} / \mathrm{L}$ dose after 90 hours of digestion.

All three hydrotalcites demonstrated an increase in production compared to the control sample with no HT addition (Table 2). Both HTs that contain Zn presented the highest methane yield; Zn-Mg-Al HT and Fe-Zn-MgAl HT had an increment of $7.4 \%$ and $8.1 \%$ respectively. Fe-Mg-Al HT had a $4.8 \%$ increment against the control. COD removal efficiencies presented the same pattern, ranging between $80-84 \%$.

Anaerobic Biodegradability (BD) of the substrates can be estimated knowing the experimental BMP and the relation between COD/VS. Considering the substrate used in this study is composed of sucrose and acetate a theoretical $1.19 \mathrm{COD} / \mathrm{VS}$ ratio can be calculated by stoichiometric oxidation of the organic material (Angelidaki \& Sanders 2004). Since it is known that the theoretical methane yield of 1 gram COD is $350 \mathrm{~mL} \mathrm{CH}$ at STP (Buffiere $\mathrm{P}$ et al. 2006). Equation 3 expresses the relation of BMP and biodegradability:

$$
B D=\frac{B M P\left(\mathrm{mLCH}_{4, S T P} / \mathrm{gVS}\right)}{350 \times C O D_{\text {waste }}(\mathrm{gCOD} / \mathrm{gVS})}
$$

Although this equation neglects the fraction of substrate used for generation of new biomass and assumes all COD is converted to methane (Owens and Chynoweth 1993), it is still a good assessment criterion for biodegradability. 
The purpose of sulfur addition to the synthetic wastewater used in the experiments was to determine if the different metal ions co-precipitated in the $\mathrm{Mg}$-Al HT had any effect on the methane potential. During anaerobic digestion, sulfate or sulfite is anaerobically reduced to sulfide by sulfate reducing bacteria. These bacteria use sulfate as a terminal electron acceptor for the degradation or organic material and hydrogen (Pol et al. 1998); moreover the sulfur reducing bacteria compete with methanogens for the produced intermediates, therefore there is less methane formation as end-product. The reduced dissolved sulfide is then present as the unionized $\mathrm{H}_{2} \mathrm{~S}$ form and as $\mathrm{HS}^{-}$. The presence of $\mathrm{H}_{2} \mathrm{~S}$ in the liquid phase reduces the COD removal efficiency and $\mathrm{H}_{2} \mathrm{~S}$ in the gas phase is an undesirable end-product of anaerobic digestion. The better performance of the HTs that contain $\mathrm{Zn}$ can be attributed to the fact that $\mathrm{Zn}^{2+}$ ions react with $\mathrm{S}^{2-}$ to yield zinc sulfide. Therefore $\mathrm{Zn}$ ions are more likely to react with sulfide and prevent it from forming $\mathrm{H}_{2} \mathrm{~S}$. The sulfur trapping ability of zinc ions is, in fact, well known in the chemical industry, where it is used at a large scale in refining and reforming processes (Wu et al. 2011). The main functionality of iron in the anaerobic digestion process is attributed to enhancing the conversion of acetic acid to methane in the methanogenesis phase (Hoban \& Berg 1979). It is interesting to note that several studies have proven the toxicity of $\mathrm{Zn}$ and $\mathrm{ZnO}$ nanoparticles on the anaerobic digestion process (Luna-delRisco et al. 2011). Also for Fe; although required for growth in microorganisms; if found in more than trace amounts is generally considered as a toxic heavy metal (Jackson-Moss and Duncan, 1990). In our study, in contrast, the $\mathrm{Zn}$ and Fe ions are chemically bonded in the hydrotalcite structure and, therefore, leaching into the system is prevented. Given the advantageous properties of $\mathrm{Fe}^{2+}$ and $\mathrm{Zn}^{2+}$ ions, a combination of both ions in the hydrotalcite structure would presumably be the most effective HT tested which is validated with the obtained results.

Table. 2. Characterization of anaerobically digested samples with HTs and calcined HTs.

\begin{tabular}{|c|c|c|c|c|c|c|}
\hline Sample HT & Initial pH & Final pH & $\begin{array}{l}\text { Ultimate } \\
\text { methane } \\
\text { yield (mL } \\
\left.\mathrm{CH}_{4} / \mathrm{gVS}\right)\end{array}$ & $\begin{array}{c}\text { COD } \\
\text { removal } \\
(\%)\end{array}$ & $\begin{array}{c}\text { Increment } \\
\text { compared to } \\
\text { control (\%) }\end{array}$ & $\begin{array}{c}\text { Anaerobic } \\
\text { biodegradabi } \\
\text { lity }(\%)\end{array}$ \\
\hline Control & 7.6 & 7.5 & 343.9 & 65.6 & N.A. & 82.6 \\
\hline $\mathrm{Fe}-\mathrm{Mg}-\mathrm{Al}$ & 7.7 & 7.5 & 360.4 & 80.1 & 4.8 & 86.5 \\
\hline $\begin{array}{l}\text { Fe-Mg-Al } \\
\text { Calcined }\end{array}$ & 7.7 & 7.4 & 342.8 & 66.1 & -0.3 & 82.3 \\
\hline Zn-Mg-Al & 7.6 & 7.4 & 369.3 & 83.7 & 7.4 & 88.7 \\
\hline $\begin{array}{l}\text { Zn-Mg-Al } \\
\text { Calcined }\end{array}$ & 7.6 & 7.5 & 345.8 & 66.9 & 0.6 & 83.0 \\
\hline $\mathrm{Fe}-\mathrm{Zn}-\mathrm{Mg}-\mathrm{Al}$ & 7.7 & 7.4 & 371.9 & 84.0 & 8.1 & 89.3 \\
\hline $\begin{array}{l}\text { Fe-Zn-Mg-Al } \\
\text { Calcined }\end{array}$ & 7.8 & 7.5 & 347.7 & 69.4 & 1.1 & 83.5 \\
\hline
\end{tabular}

The calcined forms of each of HTs were also tested at the initial concentration of $500 \mathrm{mg} / \mathrm{L}$. A minor decrease in methane production was observed for the calcined Fe-Mg-Al HT and a slight increase for the calcined $\mathrm{Zn}-\mathrm{Mg}$-Al and Fe-Zn-Mg-Al HTs (Figure 5). COD removal efficiencies were similar to the control, between 65-70\%. The 
thermal decomposition of the HT leads to a collapse in the layered structure and results in formation of mixed oxides with basic sites (Sampieri et al. 2011). Consequently, $\mathrm{Fe}^{2+}$ and $\mathrm{Zn}^{2+}$ ions are converted to $\mathrm{ZnO}$ and $\mathrm{Fe}_{2} \mathrm{O}_{3}$, respectively. As observed from figure 5 all three hydrotalcites have a noticeable increase in methane production compared to their calcined form, therefore their better efficiency is attributed to the presence of $\mathrm{Fe}^{2+}$ and $\mathrm{Zn}^{2+}$ cations incorporated and immobilized in the layered sheet structure of the hydrotalcite. Given that hydrotalcites and particularly their calcined form have strong basic properties (Xie et al. 2006), there was no apparent effect on the overall $\mathrm{pH}$ of each of the reactors. The final $\mathrm{pH}$ of all samples ranged between 7.47.5.

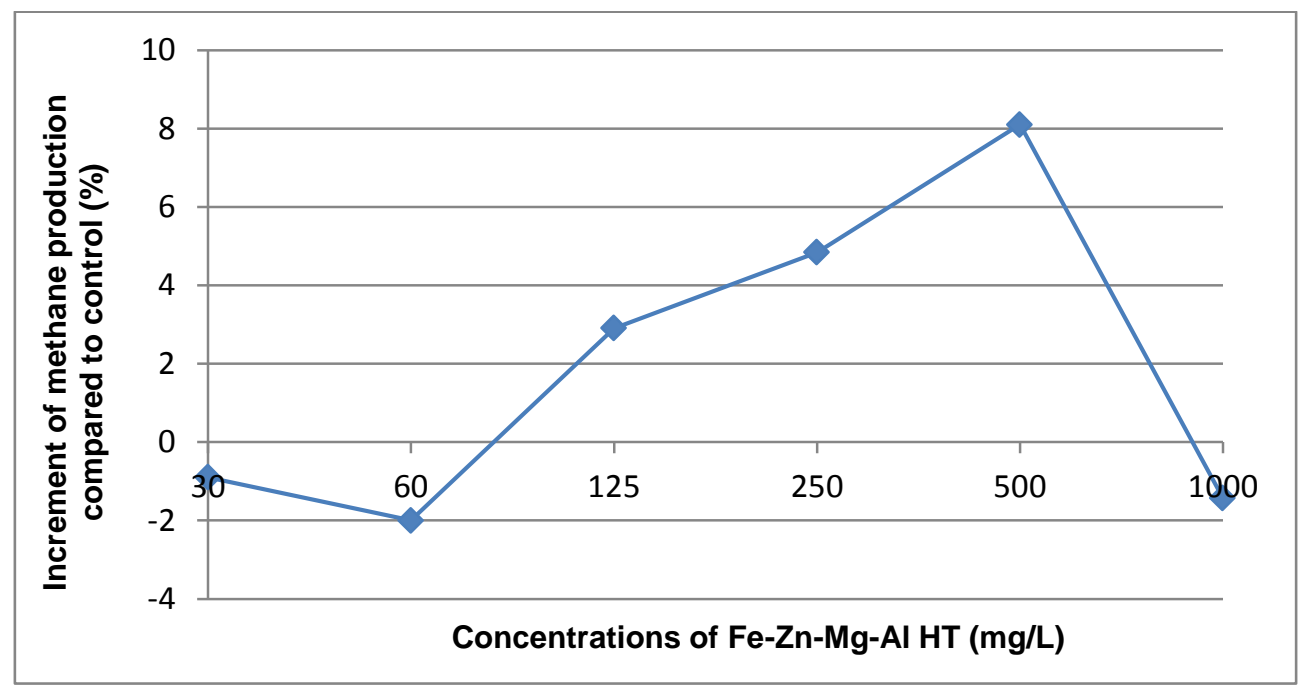

Figure 6. Percent increments of methane production at different concentrations of Fe-Zn-Mg-Al HT after 90 hours of digestion.

After determining that the Fe-Zn-Mg-Al HT presented the highest methane production, different concentrations of this HT were tested in order to determine the influence on the ultimate methane yield. In the same conditions as described previously, six concentrations were evaluated ranging from 30 to $1000 \mathrm{mg} / \mathrm{L}$ (Figure 6). The initial concentration of $500 \mathrm{mg} / \mathrm{L}$ proved to be the most effective. Concentrations of 30, 60 and $1000 \mathrm{mg} / \mathrm{L}$ presented no enhancement effect on the methane yield compared to the control. From the concentrations evaluated in this study an optimal concentration of $500 \mathrm{mg} / \mathrm{L} \mathrm{Fe}-\mathrm{Zn}-\mathrm{Mg}-\mathrm{Al} \mathrm{HT}$ can be identified. Further testing of concentrations between 500 and $1000 \mathrm{mg} / \mathrm{L}$ should be evaluated in order to determine a more exact range where methane production is boosted.

\section{Conclusions}

Three hydrotalcites of Fe-Mg-Al, Zn-Mg-Al and Fe-Zn-Mg-Al and their calcined form were prepared, characterized and tested in the anaerobic digestion of synthetic wastewater in order to evaluate the effect on the methane potential. Results showed that Fe-Zn-Mg-Al hydrotalcite at $500 \mathrm{mg} / \mathrm{L}$ presented the highest methane production of $371.9 \mathrm{~mL} \mathrm{CH} / \mathrm{gVS}$ which is $8.1 \%$ higher than the control and corresponds to $89.3 \%$ anaerobic degradability. Second best on enhancing methane production was $\mathrm{Zn}-\mathrm{Mg}$-Al HT followed by Fe-MgAl HT. Calcined hydrotalcites did not show any significant effect on the methane potential of the substrate. This 
suggests that the enhancement of methane produced by the Fe- $\mathrm{Zn}-\mathrm{Mg}$-Al hydrotalcite was related to the presence of $\mathrm{Fe}^{2+}$ and $\mathrm{Zn}^{2+}$ cations incorporated and immobilized in the layered sheet structure of the hydrotalcite.

\section{Acknowledgements}

This research was conducted under the support of the Erasmus Mundus SELECT+ Joint Doctoral Programme. The authors are grateful for the support of the staff at the Department of Forest Products Technology in Aalto University and the Institute of Energy Technologies in the Polytechnic University of Catalonia. J.L. is Serra Húnter Fellow and is grateful to ICREA Academia program.

\section{References}

Xu, S., Liu, H., Fan, Y., Schaller, R., Jiao, J., \& Chaplen, F. (2012). Enhanced performance and mechanism study of microbial electrolysis cells using Fe nanoparticle-decorated anodes. Applied Microbiology and Biotechnology, 93(2), 871-880. http://doi.org/10.1007/s00253-011-3643-2

Lv, L., He, J., Wei, M., Evans, D. G., \& Zhou, Z. (2007). Treatment of high fluoride concentration water by MgAl-CO 3 layered double hydroxides : Kinetic and equilibrium studies, 41, 1534-1542. http://doi.org/10.1016/j.watres.2006.12.033

Sekhavatjou, M. S., Moradi, R. R., Alhashemi, H. a., \& Hejabi, T. a. (2014). A new method for sulfur components removal from sour gas through application of zinc and iron oxides nanoparticles. International Journal of Environmental Research, 8(2), 273-278.

Casals, E., Barrena, R., García, A., González, E., Delgado, L., Busquets-Fité, M., ... Puntes, V. (2014). Programmed iron oxide nanoparticles disintegration in anaerobic digesters boosts biogas production. Small (Weinheim an Der Bergstrasse, Germany), 10(14), 2801-8, 2741. http://doi.org/10.1002/smll.201303703

Cocheci, L., Barvinschi, P., Pode, R., Popovici, E., \& Seftel, E. M. (2010). Structural Characterization of Some Mg / Zn-Al Type Hydrotalcites Prepared for Chromate Sorption from Wastewater, 55(3), $40-45$.

Gillman, G. P. (2006). A simple technology for arsenic removal from drinking water using hydrotalcite, 366, 926-931. http://doi.org/10.1016/j.scitotenv.2006.01.036

Setshedi, K., Ren, J., Aoyi, O. \& Onyango, M. S. (2011). Removal of Pb(II) from aqueous solution using hydrotalcite-like nanostructured material. International Journal of the Physical Sciences Vol. 7(1), pp. 63 - 72, 2. DOI: 10.5897/IJPS11.1331

Douglas, G. B., Wendling, L. A., \& Pleysier, R. (2009). HYDROTALCITE FORMATION FOR CONTAMINANT REMOVAL FROM MINING WASTEWATERS, Proceedings of the International Mine Water Conference ISBN Number: 978-0-9802623-5-3 (5), 407-414. 
Wang, H., Chen, J., Cai, Y., Ji, J., Liu, L., \& Teng, H. H. (2007). Defluoridation of drinking water by $\mathrm{Mg} / \mathrm{Al}$ hydrotalcite-like compounds and their calcined products, 35, 59-66. http://doi.org/10.1016/j.clay.2006.08.005

Wajima, T. (2014). Removal of Bromide from Desalinated Water Using Hydrotalcite, 5(2), 2-6. http://doi.org/10.7763/IJESD.2014.V5.478

Palmer, S. J., \& Frost, R. L. (2010). Use of Hydrotalcites for the Removal of Toxic Anions from Aqueous Solutions, 8969-8976.

Wimonsong, P., Llorca, J., \& Nitisoravut, R. (2013). Catalytic activity and characterization of Fe-Zn$\mathrm{Mg}-\mathrm{Al}$ hydrotalcites in biohydrogen production. International Journal of Hydrogen Energy, 38, 10284-10292.

Wimonsong, P., Nitisoravut, R., \& Llorca, J. (2014). Application of Fe-Zn-Mg-Al-O hydrotalcites supported $\mathrm{Au}$ as active nano-catalyst for fermentative hydrogen production. Chemical Engineering Journal, 253, 148-154. http://doi.org/10.1016/j.cej.2014.05.047

Carriazo, D., del Arco, M., Martín, C., \& Rives, V. (2007). A comparative study between chloride and calcined carbonate hydrotalcites as adsorbents for Cr(VI). Applied Clay Science, 37(3-4), 231239. http://doi.org/10.1016/j.clay.2007.01.006

Chynoweth, D. P., Owens, J. M., \& Legrand, R. (2001). Renewable methane from anaerobic digestion of biomass. Renewable Energy, 22(1-3), 1-8.

Mes, T. Z. D. De, Stams, A. J. M., Reith, J. H., \& Zeeman, G. (2003.). Methane production by anaerobic digestion of wastewater and solid. Chapter 4 in Biomethane and Biohydrogen. Status and perspectives of biological methane and hydrogen production. , 58-94

Bayr, S., Kaparaju, P., \& Rintala, J. (2013). Screening pretreatment methods to enhance thermophilic anaerobic digestion of pulp and paper mill wastewater treatment secondary sludge. Chemical Engineering Journal, 223, 479-486. http://doi.org/10.1016/j.cej.2013.02.119

Meyer, T., \& Edwards, E. A. (2014). Anaerobic digestion of pulp and paper mill wastewater and sludge. Water Research, 65C, 321-349. http://doi.org/10.1016/j.watres.2014.07.022

Ariunbaatar, J., Panico, A., Esposito, G., Pirozzi, F., \& Lens, P. N. L. (2014). Pretreatment methods to enhance anaerobic digestion of organic solid waste. Applied Energy, 123, 143-156. http://doi.org/10.1016/j.apenergy.2014.02.035

Kamali, M., and Khodaparast, Z. (2014). "Review on recent developments on pulp and paper mill wastewater treatment," Ecotoxicology and Environmental Safety (in press). DOI: 10.1016/j.ecoenv.2014.05.005 
Ekstrand, E.-M., Larsson, M., Truong, X.-B., Cardell, L., Borgström, Y., Björn, A., ... Karlsson, A. (2013). Methane potentials of the Swedish pulp and paper industry - A screening of wastewater effluents. Applied Energy, 112, 507-517. doi:10.1016/j.apenergy.2012.12.072

Ali, M., \& Sreekrishnan, T.R. (2001). Aquatic toxicity from pulp and paper mill effluents: a review. Advances in Environmental Research, 5(2), 175-196.

Yunqin, L., Dehan, W., \& Lishang, W. (2010). Biological pretreatment enhances biogas production in the anaerobic digestion of pulp and paper sludge. Waste Management \& Research: The Journal of the International Solid Wastes and Public Cleansing Association, ISWA, 28(9), 800-10. doi:10.1177/0734242X09358734

C A Jackson-Moss, J R Duncan. The effect of iron on anaerobic digestion. Biotechnology Letters February 1990, Volume 12, Issue 2, pp 149-154

Beckers, L., Hiligsmann, S., Lambert, S. D., Heinrichs, B., \& Thonart, P. (2013). Improving effect of metal and oxide nanoparticles encapsulated in porous silica on fermentative biohydrogen production by Clostridium butyricum. Bioresource Technology, 133, 109-17. http://doi.org/10.1016/j.biortech.2012.12.168

Salomão, R., Milena, L. M., Wakamatsu, M. H., \& Pandolfelli, V. C. (2011). Hydrotalcite synthesis via co-precipitation reactions using $\mathrm{MgO}$ and $\mathrm{Al}(\mathrm{OH}) 3$ precursors. Ceramics International, 37(8), 3063-3070. http://doi.org/10.1016/j.ceramint.2011.05.034

Patricia A. Terry, David M. Dolan, and Kendra Axness 2012. Effect of temperature, zinc, and cadmium ions on the removal of $\mathrm{Cr}$ (VI) from aqueous solution via Ion exchange with hydrotalcite. Chapter 13 Ion exchange technology II Applications Springer 2012, pp 337-347 DOI:10-1007/978-94-007-4026-6_13

Angelidaki, I., \& Sanders, W. (2004). Assessment of the anaerobic biodegradability of macropollutants. Reviews in Environmental Science and Bio/Technology, 3(2), 117-129. doi:10.1007/s11157-004-2502-3

Tichit, D., \& Coq, B. (n.d.). Catalysis by hydrotalcites and related materials.

Xie, W., Peng, H., \& Chen, L. (2006). Calcined Mg-Al hydrotalcites as solid base catalysts for methanolysis of soybean oil. Journal of Molecular Catalysis A: Chemical, 246(1-2), 24-32. doi:10.1016/j.molcata.2005.10.008

Chemetry, J. O. F. (1999). Structure and base properties of calcined hydrotalcites, (4).

Wu, C. M., Baltrusaitis, J., Gillan, E. G., \& Grassian, V. H. (2011). Sulfur dioxide adsorption on ZnO nanoparticles and nanorods. Journal of Physical Chemistry C, 115(20), 10164-10172. doi:10.1021/jp201986j 
Luna-delRisco, M., Orupõld, K., \& Dubourguier, H.-C. (2011). Particle-size effect of CuO and ZnO on biogas and methane production during anaerobic digestion. Journal of Hazardous Materials, 189(1-2), 603-8. doi:10.1016/j.jhazmat.2011.02.085

Sampieri, A., Fetter, G., Villafuerte-Castrejon, M. E., Tejeda-Cruz, A., \& Bosch, P. (2011). Twofold role of calcined hydrotalcites in the degradation of methyl parathion pesticide. Beilstein Journal of Nanotechnology, 2, 99-103. doi:10.3762/bjnano.2.11

Hoban, D. J., and van den Berg, L., "Effect of Iron on Conversion of Acetic Acid during Methanogenic Fermentations," Journal of Applied Bacteriology, Vol. 47(1), 1979, p. 153-158 